\title{
A CONTRIBUTION TO THE KNOWLEDGE OF THE ORIBATID MITE GENUS GYMNOBODES (ACARI, ORIBATIDA, CARABODIDAE)
}

\author{
Sergey G. Ermilov ${ }^{*}$ and Julien K. N'Dri ${ }^{2}$
}

\author{
${ }^{1}$ Tyumen State University, Tyumen, Russia \\ ${ }^{2}$ Nangui Abrogoua University, Abidjan, Côte d'Ivoire \\ *corresponding author; e-mail: ermilovacari@yandex.ru
}

\begin{abstract}
A new species of the genus Gymnobodes (Oribatida, Carabodidae) is described from Côte d'Ivoire. G. cotedivoirensis Ermilov sp.n. differs from the other species of the genus by the presence of translamella on the prodorsum, four longitudinal ridges and one pair of posterolateral concavities on the notogaster. A revised generic diagnosis of Gymnobodes is presented.
\end{abstract}

KEY WORDS: Carabodid mites, systematics, generic diagnosis, new species, morphology, Ethiopian region.

DOI: $10.21684 / 0132-8077-2018-26-2-161-166$

\section{INTRODUCTION}

The oribatid mite genus Gymnobodes (Acari, Oribatida, Carabodidae) was proposed by Balogh (1965), with Carabodes fraterculus Balogh, 1963 as the type species. At present, it comprises four species, which are distributed in the Ethiopian, Neotropical and Oriental regions (Ermilov 2016). An identification key to the known species of the genus is presented by Ermilov (2016).

Among the material collected from Côte d'Ivoire, we found a new species of Gymnobodes. The main goals of the paper include (a) describing and illustrating this new species, as well as (b) proposing a revised generic diagnosis of Gymnobodes.

At present, the oribatid mite fauna of Côte d'Ivoire is poorly investigated, and only three species of Carabodidae are known from this country: Congocepheus heterotrichus Balogh, 1958; Kalloia simpliseta Mahunka, 1985; and Machadocepheus leoneae Fernández, Theron, Rollard and Leiva, 2014 (Ermilov and N'Dri 2018).

\section{MATERIAL AND METHODS}

The details of the collection locality and habitat are provided in the "Material examined" section below.

Specimens were mounted in lactic acid on temporary cavity slides for measurement and illustration. Body length was measured in lateral view, from the tip of the rostrum to the posterior edge of the notogaster. Notogastral width refers to the maximum width of the notogaster in dorsal view. Lengths of body setae were measured in lateral aspect. All body measurements are presented in micrometers. Formulas for leg setation are given in parentheses according to the sequence trochanter-femur-genu-tibia-tarsus (famulus included). Formulas for leg solenidia are given in square brackets according to the sequence genutibia-tarsus.

Drawings were made with a camera lucida using a Leica transmission light microscope "Leica DM 2500".

Morphological terminology used in this paper follows that of F. Grandjean: see Travé and Vachon (1975) for references, Norton (1977) for leg setal nomenclature, and Norton and Behan-Pelletier (2009) for overview.

The following abbreviations are used: con-concavity; $r$-ridge; ro, le, in, $b s$ - rostral, lamellar, interlamellar and bothridial setae, respectively; $c$, $l a, l m, l p, h, p$ - notogastral setae; $i a, i m$, ip - notogastral lyrifissures; gla - opisthonotal gland opening; $h, m, a$-subcapitular setae; $v, l, d, c m, u l$, sul, $v t$, $l t$ - palp setae; $\omega$ - palp and leg solenidion; cha, chb - cheliceral setae; $P d I, P d I I$ - pedotecta I, II, respectively; $1 b, 1 c, 2 a, 3 a, 3 b, 3 c, 4 a, 4 b, 4 c$ - epimeral setae; dis-discidium; $g$, $a g$, an, ad-genital, aggenital, anal and adanal setae, respectively; $\sigma$, $\varphi$ - leg solenidia; $\varepsilon$ - leg famulus; $v, e v, b v, l, d, f t$, tc, it, $p, u, a, s, p v-\operatorname{leg}$ setae.

\section{SYSTEMATICS}

\section{Superfamily Carabodoidea}

Family Carabodidae

Genus Gymnobodes Balogh, 1965

Type species Carabodes fraterculus Balogh, 1963

\section{Gymnobodes cotedivoirensis Ermilov sp.n.}

(Figs. 1-10)

Diagnosis. Body size: $298-348 \times 132-166$. Lateral and posterior parts of notogaster densely tuberculate. Prodorsum with triangular concavity basally. Translamella present. Rostral, lamellar and 


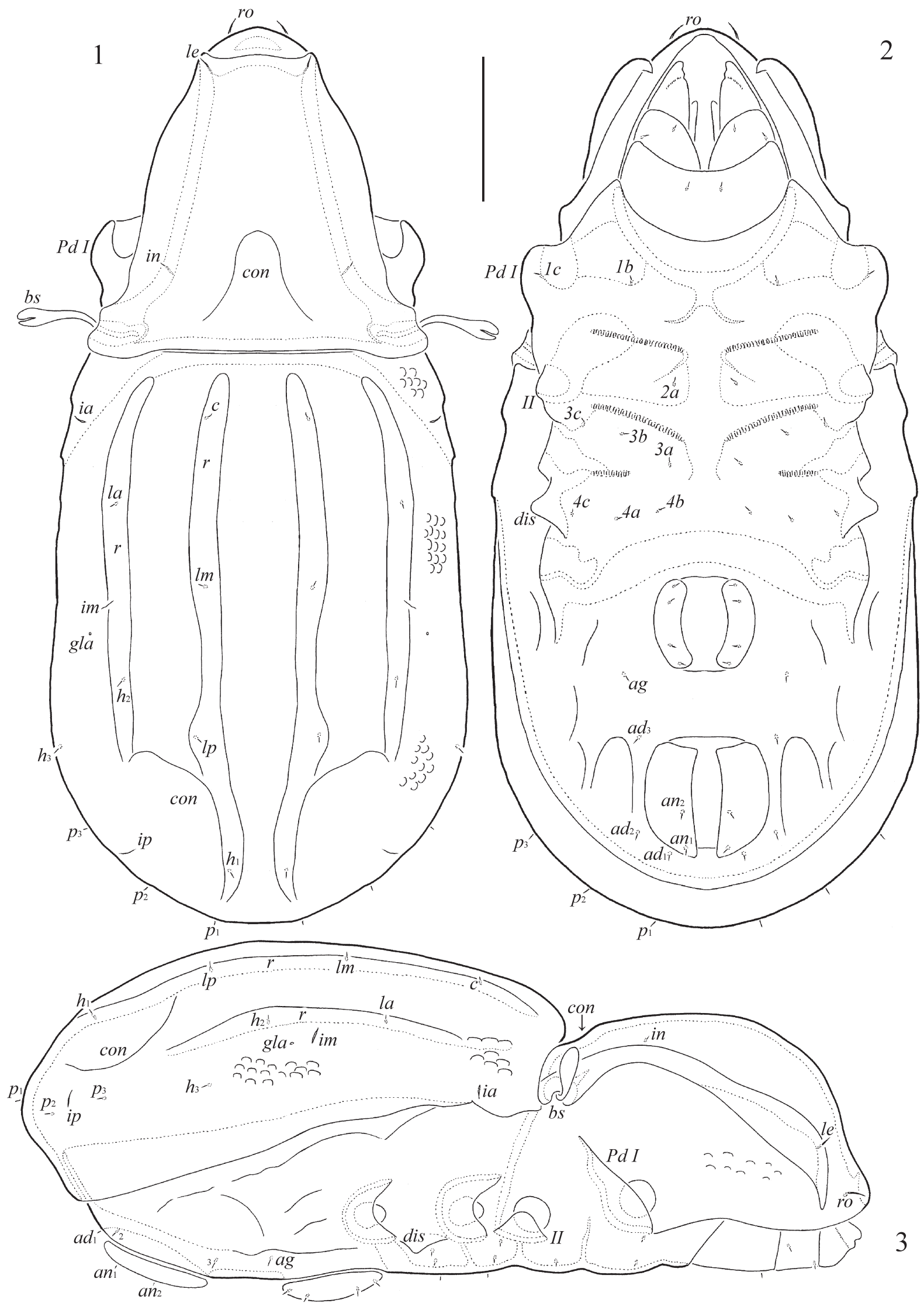

Figs. 1-3. Gymnobodes cotedivoirensis Ermilov sp.n., adult: 1-dorsal view (legs not illustrated); 2-ventral view (legs not illustrated); 3 -lateral view (legs not illustrated). Scale bar $=50 \mu \mathrm{m}$. 


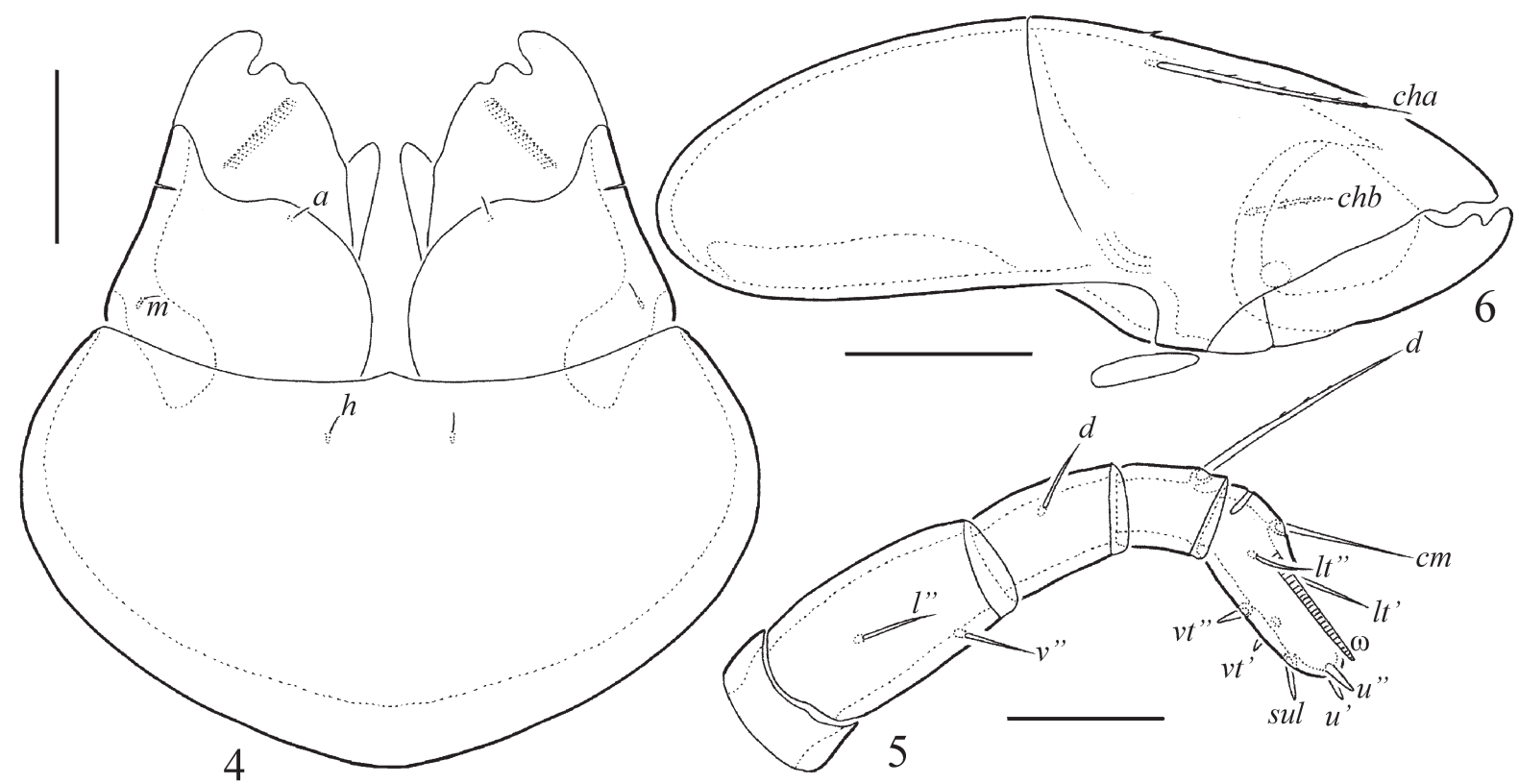

Figs. 4-6. Gymnobodes cotedivoirensis Ermilov sp.n., adult: 4—subcapitulum (pressed), ventral view; 5-palp, right, antiaxial view; 6-chelicera, left, paraxial view. Scale bars $=20 \mu \mathrm{m}(4,6), 10 \mu \mathrm{m}(5)$.

interlamellar setae short, setiform, thin, smooth, ro longest, in shortest. Bothridial setae clavate, smooth. Notogaster with four longitudinal ridges and one pair of posterolateral concavities. Notogastral, epimeral and anogenital setae short, setiform, thin, smooth. Epimeral setal formula 2-1-3-3. Leg genua I and II with 3 setae.

Description. Measurements. Body length: 348 (holotype, female), 298-348 (six paratypes, all females); notogaster width: 166 (holotype), 132166 (six paratypes).

Integument (Figs. 1, 3). Body color yellow brown to brown. Body and legs covered by amorphous colorless cetrotegument. Surface smooth except lateral and posterior parts of notogaster having dense tubercles (their diameter up to 4 ) and pedotecta I and lateral parts of prodorsum having slightly developed sparse foveoles (their diameter up to 2).

Prodorsum (Figs. 1-3). Rostrum broadly rounded. Basal part of prodorsum with triangular concavity (1/6 length of prodorsum) medially. Lamellae very long (little shorter than length of prodorsum), with typical strong distal tooth-like processes. Translamella present, slightly developed, visible in dorsal view. Rostral (8-10), lamellar (4-6) and interlamellar (2-4) setae setiform, thin, smooth. Bothridial setae (32-36) clavate, with heads split dorsomedially, smooth. Bothridia located in the basal part of prodorsum, connected with margins of the lamellae, interrupted ventrally.
Exobothridial setae and their alveoli absent. Tutoria absent.

Notogaster (Figs. 1-3). Anterior margin distinct, straight. Posterior margin broadly rounded. Dorsal side with four longitudinal ridges and one pair of posterolateral concavities. Humeral shoulders slightly developed, rectangular. Ten pairs of notogastral setae (2-4) setiform, thin, smooth. Setae $c, l m, l p$ and $h_{1}$ inserted on medial ridges, $l a$ and $h_{2}$ on lateral ridges. Posterior half of notogaster with four pairs of setae $\left(p_{1}, p_{2}, p_{3}\right.$ and $\left.h_{3}\right)$. Lyrifissures (except $i h$ and ips not visible) and opisthonotal gland openings distinct; ia located on humeral shoulders, im and gla-between la and $h_{2}$, ip - between $p_{2}$ and $p_{3}$.

Gnathosoma (Figs. 2, 4-6). Subcapitulum longer than wide (69-77 $\times 53-57)$. Subcapitular setae similar in length (2-4), setiform, thin, smooth. Postpalpal setae (6) spiniform, smooth. Adoral setae and their alveoli absent. Palps (41-45) with setation $0-2-1-3-8(+\omega)$. Setae $\mathrm{acm}$ absent. Solenidion of palptarsi long, bacilliform. Chelicerae (90-98) with two setiform, barbed setae, cha (28-32) longer than chb (10-12). Trägårdh's organ of chelicerae not founded.

Epimeral and lateral podosomal regions (Figs. 2, 3). Epimeral setal formula 2-1-3-3. Setae (2-4) setiform, thin, smooth. Pedotecta I represented by large and broad scales, pedotecta II represented by small scales, broadly rounded in ventral view. Discidia triangular, rounded distally. 


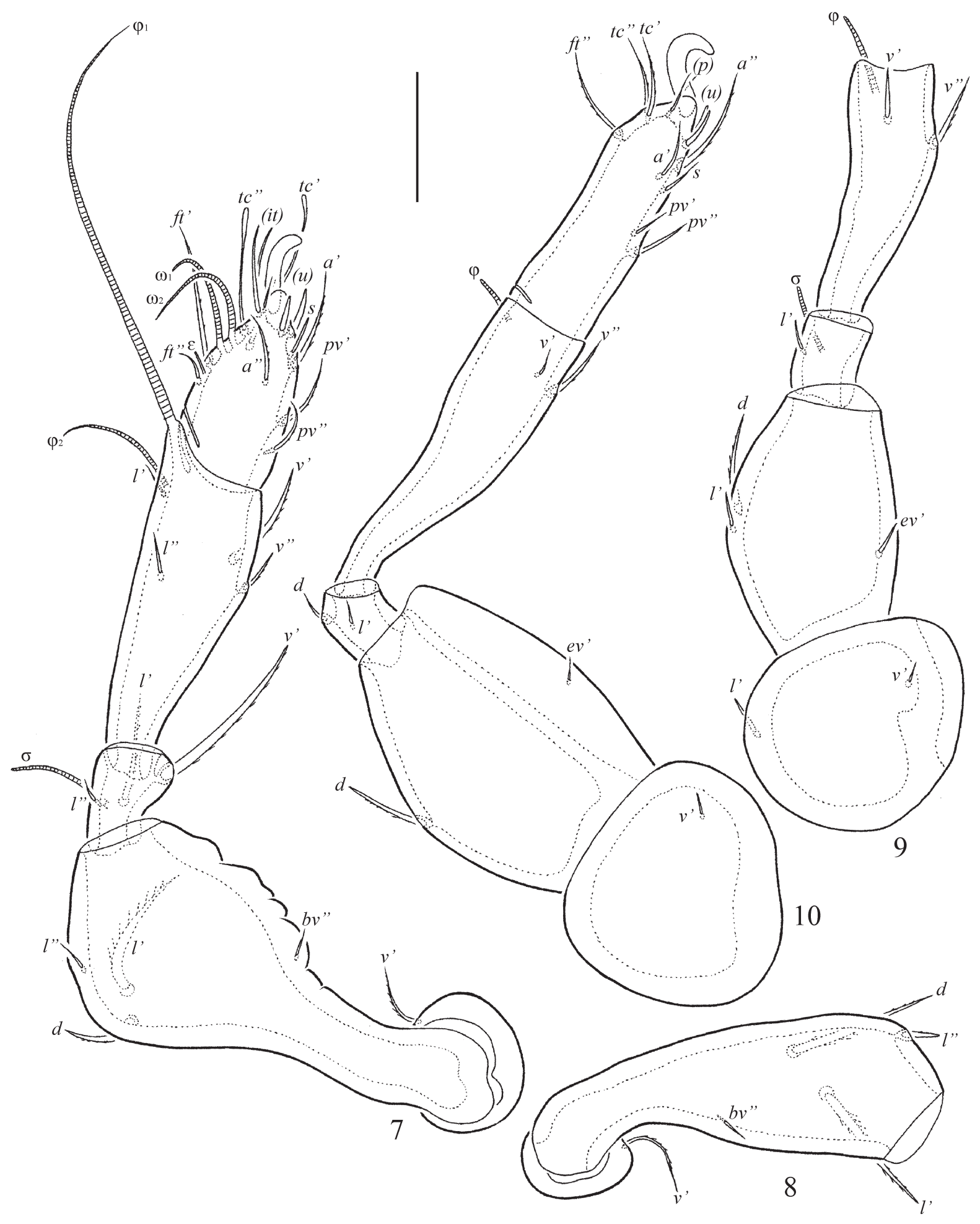

Figs. 7-10. Gymnobodes cotedivoirensis Ermilov sp.n., adult: 7-leg I, right, antiaxial view; 8-trochanter and femur of leg II, right, antiaxial view; 9-leg III, without tarsus, left, antiaxial view; 10-leg IV, left, antiaxial view. Scale bar $=20 \mu \mathrm{m}$.

Anogenital region (Figs. 2, 3). Ventrolateral parts with some depressions. Four pairs of genital, one pair of aggenital, two pairs of anal and three pairs of adanal setae similar in length (2-4), setiform, thin, smooth. Adanal lyrifissures not visible.
Legs (Figs. 7-10). Claw of each leg strong, smooth. Porose areas on all femora and on trochanters III, IV poorly visible. Formulas of leg setation and solenidia: I (1-4-3-4-16) [1-2-2], II (1-4-3$3-15)$ [1-1-2], III (2-3-1-2-15) [1-1-0], IV (1- 
$2-2-2-12$ ) [0-1-0]; homology of setae and solenidia indicated in Table 1.

Material examined. Côte d'Ivoire, $5^{\circ} 13^{\prime} \mathrm{N}$, $5^{\circ} 03^{\prime} \mathrm{W}$, Grand-Lahou Department, 7-year-old rubber plantations. Plant litter was collected by Julien K. N'Dri, during the dry season, January-March, 2013. Mites were extracted from litter samples with Berlese's funnels, using electric lamp (25W), over the course of 10 days in the laboratory.

Type deposition. In ethanol with a drop of glycerol. Holotype (female) and one paratype (female): Senckenberg Institute, Görlitz, Germany. Five paratypes (all females): Tyumen State University Museum of Zoology, Tyumen, Russia.

Etymology. The species name refers to the country of origin, Côte d'Ivoire.

Differential diagnosis. Gymnobodes cotedivoirensis Ermilov sp.n. differs from the other species of Gymnobodes: G. fraterculus (Balogh, 1963) from the Ethiopian region; G. minimus Ermilov, 2016 from Cuba; G. semengok Mahunka, 1996 from Borneo; G. subnudus (Balogh, 1963) from Congo (see Balogh 1963, 1965; Mahunka 1996; Ermilov 2016). The new species is different in that it has translamella on the prodorsum, four longitudinal ridges and one pair of posterolateral concavities on the notogaster (these features are absent in the other species listed above).

\section{Revised generic diagnosis of Gymnobodes}

Adult. Carabodidae (e.g., Mahunka 1986; Norton and Behan-Pelletier 2009). Body elongated, ratio $($ length/width $) \approx 2.0-2.4$. Body surface partially or completely tuberculate. Rostral margin rounded. Lamellae long, broad, well separated, located dorsolaterally, with triangular processes distally. Translamella absent or present. Interlamellar processes and dorsosejugal depressions absent. Basal part of prodorsum without or with median concavity. Tutoria absent or slightly developed, lineate. Rostral, lamellar, interlamellar, notogastral, epimeral and anogenital setae minute, thin, smooth (exception: medium size, setiform, barbed); ro inserted on the prodorsum near rostrum, le and in on the prodorsum dorsolateral to lamellae or on medial parts of lamellae. Bothridial setae with well-developed heads. Notogaster without large apophyses and processes. Ten pairs of notogastral setae widely spaced, humeral shoulders without setae, posterolateral part of notogaster with four pairs of setae $\left(h_{3}, p_{1}-p_{3}\right)$. Epimeral setal formula 1(or 2)-1-3-3. Anogenital formula 4-1(or 0)-2-3. Adanal setae $a d_{1}$ posterior, $a d_{2}$ posterolateral, $a d_{3}$ anterolateral or anterior to anal plates. Adanal lyrifissures distanced from anal apertures. Leg tarsi IV with complete setation (12 setae).

Juvenile instars. Not known.

\section{ACKNOWLEDGEMENTS}

We gratefully acknowledge the contributions of the farmers and of the SODEFOR's administrator who kindly allowed access to their land. This study was funded by the International Foundation for Science / Ref. D/5287-1.

\section{REFERENCES}

Balogh, J. 1963. Oribates (Acari) nouveaux d'Angola et du Congo ( $3^{\text {ème }}$ série). Compahnia de Diamantes de Angola, Lisboa, 68: 35-47.

Balogh, J. 1965. A synopsis of the world oribatid (Acari) genera. Acta Zoologica Academiae Scientiarum Hungaricae, 11 (1-2): 5-99.

Ermilov, S.G. 2016. Contribution to the knowledge of carabodid oribatid mites (Acari, Oribatida, Carabodidae) of Cuba. Acarologia, 56 (1): 33-43.

Ermilov, S.G. and N'Dri, J.K. 2018. Oribatid mites (Acari, Oribatida) from the Oumé region (Côte d'Ivoire): list of taxa, new findings, description of a new species. Biologia, 73 (9): 867-873.

Mahunka, S. 1986. A survey of the family Carabodidae C.L. Koch, 1836 (Acari: Oribatida). Acta Zoologica Hungarica, 32 (1-2): 73-135.

Mahunka, S. 1996. Oribatids from Sarawak I (Acari: Oribatida). New and interesting mites from the Geneva Museum LXXVIII. Revue Suisse de Zoologie, 103 (1): 259-282.

Norton, R.A. 1977. A review of F. Grandjean's system of leg chaetotaxy in the Oribatei (Acari) and its application to the family Damaeidae. In: D.L. Dindal (Ed.). Biology of oribatid mites. SUNY College of Environmental Science and Forestry, Syracuse, pp. 33-61.

Norton, R.A. and Behan-Pelletier, V.M. 2009. Suborder Oribatida. Chapter 15.In: G.W. Krantz and D.E. Walter (Eds.). A Manual of Acarology. Texas Tech University Press, Lubbock, pp. 430-564.

Travé, J. and Vachon, M. 1975. François Grandjean. 1882-1975 (Notice biographique et bibliographique). Acarologia, 17 (1): 1-19. 
Table 1

Leg setation and solenidia of adult Gymnobodes cotedivoirensis Ermilov sp.n.

\begin{tabular}{|l|l|l|l|l|l|}
\hline Leg & Tr & Fe & Ge & Ti & Ta \\
\hline I & $v^{\prime}$ & $d,(l), b v^{\prime}$ & $(l), v^{\prime}, \sigma$ & $(l),(v), \varphi_{1}, \varphi_{2}$ & $(f t),(t c),(i t),(p),(u),(a), s,(p v), \varepsilon, \omega_{1}, \omega_{2}$ \\
\hline II & $v^{\prime}$ & $d,(l), b v^{\prime}$ & $(l), v^{\prime}, \sigma$ & $(l), v^{\prime}, \varphi$ & $(f t),(t c),(i t),(p),(u),(a), s,(p v), \omega_{1}, \omega_{2}$ \\
\hline III & $l^{\prime}, v^{\prime}$ & $d, l^{\prime}, e v^{\prime}$ & $l^{\prime}, \sigma$ & $(v), \varphi$ & $(f t),(t c),(i t),(p),(u),(a), s,(p v)$ \\
\hline IV & $v^{\prime}$ & $d, e v^{\prime}$ & $d, l^{\prime}$ & $(v), \varphi$ & $f t^{\prime},(t c),(p),(u),(a), s,(p v)$ \\
\hline
\end{tabular}

Roman letters refer to normal setae, Greek letters - to solenidia (except $\varepsilon$ = famulus). Single prime (') marks setae on the anterior, and double prime (") - setae on the posterior side of a given leg segment. Parentheses refer to a pair of setae. 